\title{
IDENTIFICATION OF INTEFERENCE HV LINE PROTECTION IN PLGTU PT PJB GRESIK GENERATION UNIT USING METHOD RCFA AND FDT
}

\author{
${ }^{1}$ Resti Pranandari, ${ }^{2}$ Misbah, ${ }^{3}$ Deny Irawan \\ 1,2,3 Electrical Engineering, Universitas Muhammadiyah Gresik \\ ${ }^{1}$ restiananda10@gmail.com, ${ }^{2}$ misbah@umg.ac.id and ${ }^{3}$ den2mas@umg.ac.id
}

\begin{abstract}
In the electricity generation business in Indonesia, power plants requiring to be reliable when operating and ready when needed due to network load requirements. It has been written in the performance target contract for each unit, therefore the protection system installed at the power plant must be well. The problem that occurs at the PLTGU PT PJB Gresik Generation Unit is a malfunction in the HV Line protection system that causes the generator unit to trip, thus causing questions regarding the cause of the problem that occurs. Therefore, the article purposes identification of $\mathrm{HV}$ Line Protection Interference at PLTGU PT PJB Gresik Generation Unit Using RCFA and FDT Methods. Roat Cause Failure Analysis (RCFA) RCFA is a problem-solving method using a step by step method to reveal the basic cause of a failure or damage and FDT is Failure Defense Task. It can find out the source of the problem that occurs so that it does not occur repeatedly. The benefit that can take is knowing the problem cause of the HV Line protection system malfunction so that it can be done correctly and on target for future unit reliability.
\end{abstract}

Keywords: electric power system, HV Line protection system, RCFA, and FDT.

\section{INTRODUCTION}

At PLTGU UP Gresik, a system is needed protection. The intermediate protection system is used for generators, motors, transformers, and HV Lines. In the HV line protection, there is Brake Failure protection, Branch and Breaker Failure, Sf6 Protection. On December 18, 2016, there was a disturbance at GT 1.3 which caused the trip unit to a total loss of IDR 315,828,521.00 and on March 5, 2017, the trip unit with a total loss of IDR 316,168,791.00 At ST 1.0 there was the same disturbance, namely, on July 20, 2017, with a malfunction in the HV Line protection system which caused the unit to trip with a total loss reached IDR 363,097,421.00, even though there is no alarm appears on the side transmission and at the PLTGU.

This study uses the Root Cause Failure Analysis (RCFA) and Failure Defense Task (FDT) methods. As the author's reference in making thesis using the RCFA method, namely the Journal by Weling and Arino, Mechanical Engineering Faculty, Institute of Technology Sepuluh Nopember (ITS) with the title "Maintenance Planning Process on a Flash Gas Compressor" analysis using RCFA and the results obtained that the component that causes damage is the lubrication system.

\section{METHOD}

To find an observation solution, the study of HV line protection failure, steps need to describe the approach and model of the problem.

Figure 1 shows the steps have taken in the research method. Explanation of problem solving flow chart in this study is as follows:

1. Problem Identification

2. Field Study

3. Literature Review

4. Problem Formulation

5. Research Purpose

6. Data Collection

In table 1 , the following are the steps in the data collection method

Table 1 data collection

\begin{tabular}{|c|c|c|c|}
\hline No & Data Type & $\begin{array}{l}\text { Collecting Data } \\
\text { Method }\end{array}$ & Data Source \\
\hline 1. & $\begin{array}{ll}\text { HV } & \text { Live } \\
\text { principle } & \end{array}$ & Read & $\begin{array}{l}\text { Book and } \\
\text { References }\end{array}$ \\
\hline 2. & $\begin{array}{l}\text { HV Line } \\
\text { Operation Data }\end{array}$ & $\begin{array}{l}\text { Retrieve Data } \\
\text { From Operation } \\
\text { Rendal }\end{array}$ & $\begin{array}{l}\text { Production } \\
\text { Operator and } \\
\text { Operation } \\
\text { Rendal } \\
\end{array}$ \\
\hline 3. & $\begin{array}{l}\mathrm{HV} \text { Line } \\
\text { Damage Data }\end{array}$ & $\begin{array}{l}\text { Retrieve Data } \\
\text { From Operation } \\
\text { Rendal }\end{array}$ & Engin \\
\hline
\end{tabular}




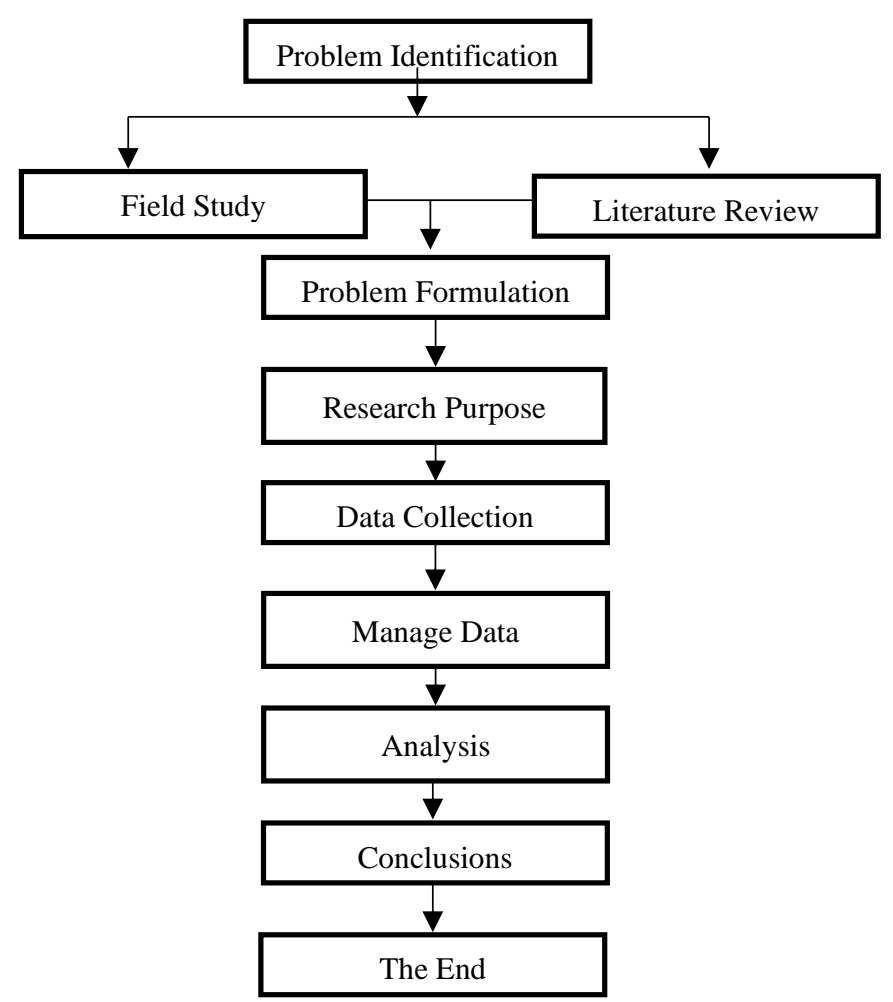

Figure 1. research methodology flow chart

\section{RESULT AND DISCUSSION}

From the research that has been carried out in the area of PT PJB Gresik Generation Unit, obtained data related to the problem and research objectives "Identification of HV Line Protection Interference at PLTGU Gresik Generation Unit Using RCFA and FDT Methods." To find out the cause of the HV Line Protection, which resulted in Unit Trips, data collection and analysis were carried out using the RCFA method which contained a Fishbone diagram to find out the dominant failure mode that occurred which resulted in the HV line protection trip. And the domination failure mode is analyzed again in more depth to find out the root of the problem that is the cause of the failure mode, which will give a suggestion or Failure Defense Task (FDT) form.

- Failure Breaker Principle

Circuit Breaker Failure (CBF) is protected in the event of a PMT trip failure, it will order the entire PMT trip. The breaker failure protection system (CBF) operates when the local relay issues a trip command, but the breaker (PMT) fails to open to cut the fault current.

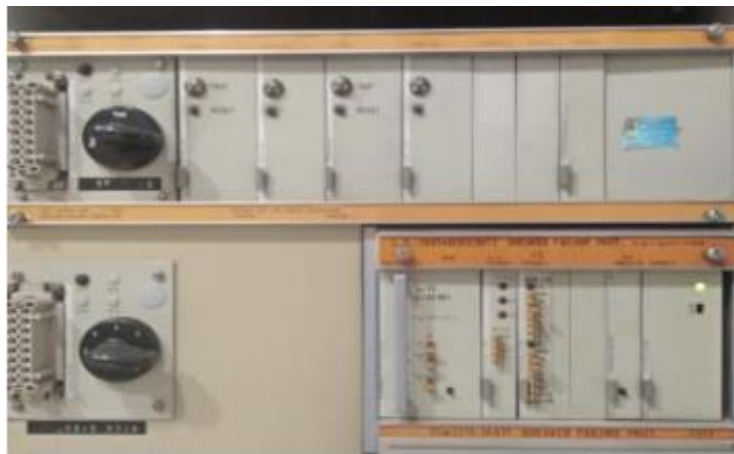

Figure 2. breaker failure

- Branch Breaker Failure

Branch Breaker Failure (BBF) is a branching point in the transmission system. There is a protection system for these branches for network reliability.

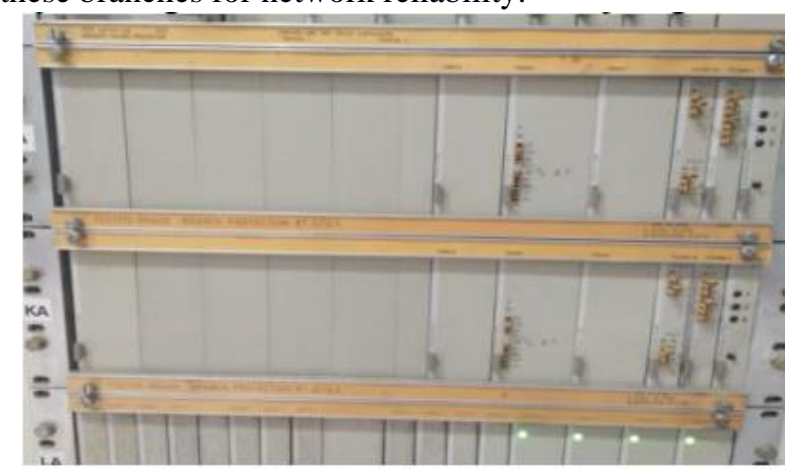

Figure 3. branch breaker failure

- $\quad$ Roat Cause Failure Analysis (RCFA)

RCFA is a problem-solving method using a step-bystep method to reveal the basic cause of a failure or damage. In this study, the RCFA method consists of several steps in analyzing:

1. Problem History

2. Fishbone Diagram

3. Measurement Data

4. Cost-Benefit

5. Generator Performance

\section{a. Problem History}

Events based on GT 1.3 Operations Report

Problem Time

Day/Date: 18 December 2016

Hours: 17.03 WIB

Technical Data

Name of Power Plant : PLTGU UP

Unit No

: GT 1.3

Brand/Type

: Mitsubishi Japan

Year of Operation

: 1993

Problem Chronology 


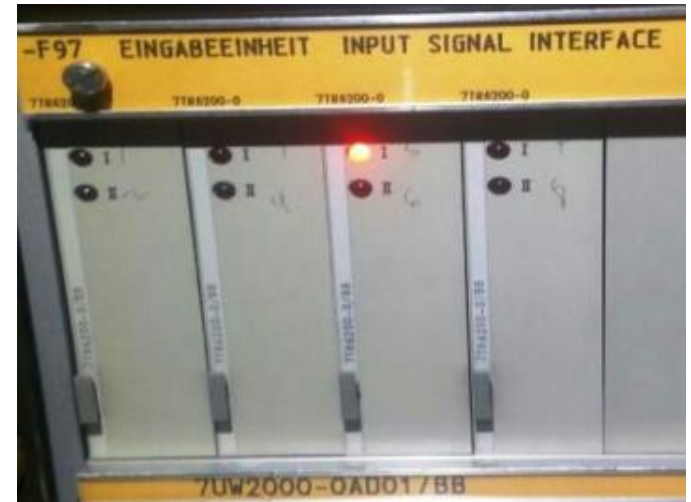

Figure 4. GTG No.3 HV Line protection trip alarm

In figure 4. There is an alarm on GTG no.3 indicating the HV Line protection trip which gives trip orders to the unit generator.

Indicator:

In the event trace OPS alarm block 1 18.21 Alarm GTG NO.3 HV LINE Prot. Trip 18:21 Alarm NO 3 GT Electrical Fault Trip 18:21 Alarm NO 3 GTG MCB Open 18:21 \#3GT Trip

In DDC:

No. 14 matrices: Under Frequency

No. 30 matrices: Branch and breaker failure prot

In table 2, the following is the load (MW) on the unit generator before and after the distraction.

Table 2 load before and after disturbance GT 1.3

\begin{tabular}{cccc} 
No & Unit & $\begin{array}{c}\text { Load Before } \\
\text { Distraction }\end{array}$ & $\begin{array}{c}\text { Load After } \\
\text { Distraction }\end{array}$ \\
\hline 1. & GT \#1.1 & $66 \mathrm{MW}$ & $66 \mathrm{MW}$ \\
\hline 2. & GT \#1.2 & $66 \mathrm{MW}$ & $66 \mathrm{MW}$ \\
\hline 3. & GT \#1.3 & $66 \mathrm{MW}$ & $0 \mathrm{MW}$ \\
\hline 4 & GT \#1.4 & $125 \mathrm{MW}$ & $11 \mathrm{MW}$
\end{tabular}

\section{b. Problem History}

Events based on ST 1.0 Operations Report Problem Time

Day/Date : 20 July 2017

Hours : $06.36 \mathrm{WIB}$

Technical Data

Name of Power Plant : PLTGU UP

Unit No

: ST 1.0

Brand/Type : Mitsubishi Japan

Year of Operation : : 1993

Problem Chronology

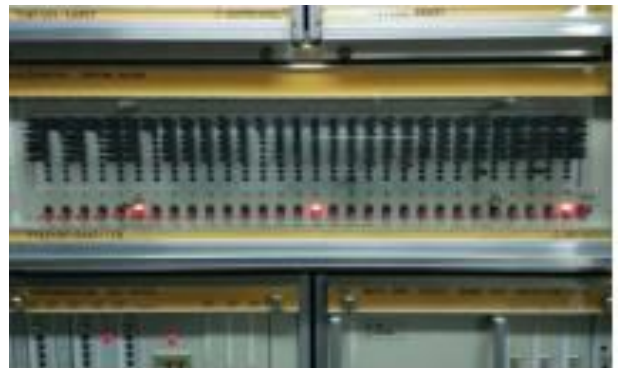

Figure 5. STG No.3 HV Line protection trip alarm

In figure 5. There is an alarm on STG no.1 indicating that HV Line protection trip which gives trip orders to the unit generator.

Indicator:

In the event trace OPS alarm block 1

06.36 Alarm STG NO.1 HV LINE PROTECTION TRIP

06.36 Alarm ST Generator Trip Condition

06.36 Alarm ST Trip On

Generator Protection Panel ST \#1.0:

No. 06 matrix: Reverse Power

No. 16 matrices: Excitation Failure

No. 30 matrices: Branch and Breaker Failure Protection

In table 3, the following is the load (MW) on the unit generator before and after the distraction.

Table 3. Load before and after disturbance ST 1.0

\begin{tabular}{cccc} 
No & Unit & $\begin{array}{c}\text { Load Before } \\
\text { Distraction }\end{array}$ & $\begin{array}{c}\text { Load After } \\
\text { Distraction }\end{array}$ \\
\hline 1. & GT \#1.1 & $57 \mathrm{MW}$ & $59 \mathrm{MW}$ \\
\hline 2. & GT \#1.2 & $0 \mathrm{MW}(\mathrm{PO})$ & $0 \mathrm{MW}(\mathrm{PO})$ \\
\hline 3. & GT \#1.3 & $57 \mathrm{MW}$ & $59 \mathrm{MW}$ \\
\hline 4 & GT \#1.0 & $80 \mathrm{MW}$ & $0 \mathrm{MW}$
\end{tabular}

- Cause and Analysis

a. Fish Bone Diagram HV Line Protection

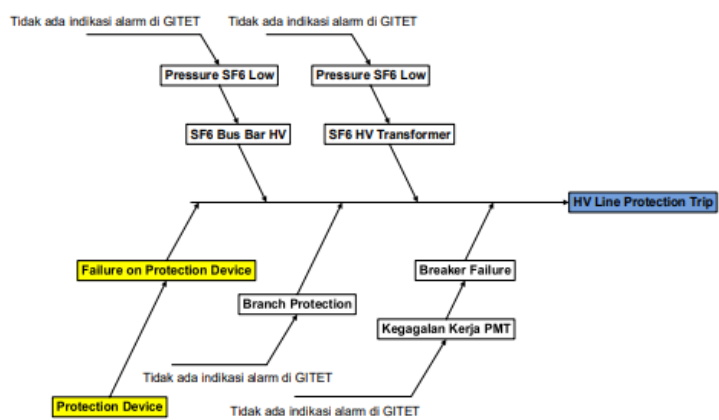

Figure 6. fishbone diagram of protection HV Line and equipment support on protection HV Line

Check for possible unit faults as follows:

- Work in the PLGTU area

a. F97 input cable looping test 
b. Megger input cable to F97 channel 1 and channel 2 (cable from the direction of GITET to PLGTU)

- Jobs in the GITET area:

a. Check the contacts of the BBF protection F513

b. Measurement of contact resistance value of the BBF relay protection F513

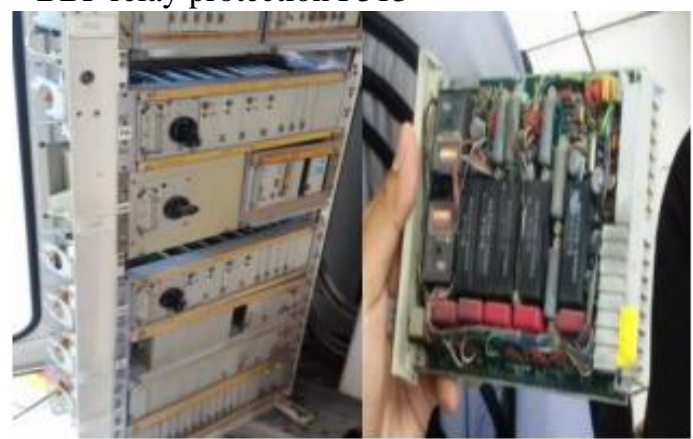

Figure 7 examinations and relay installation in PLGTU and GITET area

1.) F97 input cable looping test In table 4, the following is the looping test for F97 input cable from GITET direction to PLGTU.

Table 4 F97 input cable looping

\begin{tabular}{|c|c|c|c|}
\hline $\begin{array}{c}\text { GITET's } \\
\text { Alarm }\end{array}$ & $\begin{array}{c}\text { Cable } \\
\text { Tagging }\end{array}$ & $\begin{array}{c}\text { Target } \\
\text { Trip UP } \\
\text { Gresik }\end{array}$ & Conclusion \\
\hline $\begin{array}{l}\text { Branch \& } \\
\text { Breaker } \\
\text { Failure } \\
\text { Protection }\end{array}$ & $\begin{array}{r}\text { C-X841-2 } \\
\rightarrow X 41-39\end{array}$ & $\begin{array}{l}\text { - Coupling } \\
\text { module } \\
\text { F97 } \\
\text { - CHI } \\
\text { - Matrix } 30\end{array}$ & Normal \\
\hline $\begin{array}{l}\text { Branch \& } \\
\text { Breaker } \\
\text { Failure } \\
\text { Protection }\end{array}$ & $\begin{array}{r}\text { C-X831-2 } \\
\rightarrow \text { X41-40 } \\
\text { C-X831-1 } \\
\rightarrow \text { X41-6 }\end{array}$ & $\begin{array}{l}\text { - Coupling } \\
\text { module } \\
\text { F97 } \\
\text { - } \mathrm{CH} 2 \\
\text { - Matrix } 30\end{array}$ & Normal \\
\hline $\begin{array}{l}\text { Sf6 } \\
\text { Protection }\end{array}$ & & & \\
\hline
\end{tabular}

2.) Impedance Resistance Test (Megger)

In table 5, following the Megger F97 input cable from the GITET direction to the PLGTU.

Table 5 megger input cable to F97 results

\begin{tabular}{ccc} 
Cable Tagging & $\begin{array}{c}\text { Resistance } \\
\text { Value }\end{array}$ & Conclusion \\
\hline $\begin{array}{c}\text { C-X841-2 } \rightarrow \text { X41 } \\
-39 \text { (to Ground) }\end{array}$ & 1500 Mohm & 1500 Mohm \\
\hline $\begin{array}{c}\text { C-X841-1 } \rightarrow \text { X41- } \\
5 \text { (to Ground) }\end{array}$ & 1500 Mohm & 1500 Mohm \\
\hline $\mathrm{C}-\mathrm{X} 841-2 \rightarrow \mathrm{X} 41$ & & \\
-39 to C-X841-1 & 0L & 1500 Mohm \\
$\rightarrow$ X41-5 & &
\end{tabular}

\begin{tabular}{|c|c|c|}
\hline $\begin{array}{c}\mathrm{C}-\mathrm{X} 831-2 \longrightarrow \mathrm{X} 41- \\
40 \text { (to Ground) }\end{array}$ & 1500 Mohm & 1500 Mohm \\
\hline $\begin{array}{l}\mathrm{C}-\mathrm{X} 831-1 \longrightarrow \mathrm{X} 41- \\
6 \text { (to Ground) }\end{array}$ & $1500 \mathrm{Mohm}$ & 1500 Mohm \\
\hline $\mathrm{C}-\mathrm{X} 831-2 \longrightarrow \mathrm{X} 41$ & & \\
\hline $\begin{array}{l}-40 \text { to } C-X 831-1 \\
\rightarrow X 41-6\end{array}$ & $\mathrm{OL}$ & 1500 Mohm \\
\hline
\end{tabular}

b. Fish Bone Diagram of Branch Breaker Failure

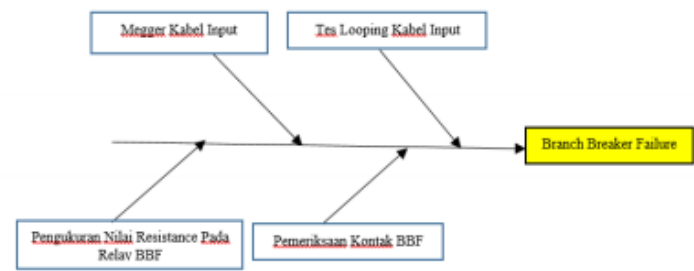

Figure 7. fishbone diagram BBF

In figure 7, Fishbone Diagram on Branch Breaker Failure which includes input cable looping test, cable megger, measurement resistance value, and checking the BBF contacts.

- Work in the PLGTU area

a. F97 input cable looping test

b. Megger input cable to F97

c. Measurement of the resistance contact value on Branch Breaker Failure relay

1.) F97 input cable looping test In table 6, following is the looping test for F97 input cable from GITET direction to PLGTU.

\begin{tabular}{lcll}
\multicolumn{4}{c}{ Table 6 F97 input cable looping } \\
\multicolumn{1}{c}{ Glarm } & $\begin{array}{c}\text { Cable } \\
\text { Tagging }\end{array}$ & $\begin{array}{l}\text { Target Trip } \\
\text { UP Gresik }\end{array}$ & $\begin{array}{l}\text { Concl } \\
\text { usion }\end{array}$ \\
\hline Branch \& & C-X841-2 & - Coupling & Norm \\
Breaker Failure & $\rightarrow$ X41-39 & module F97 & al \\
Protection & & - CHI & \\
& C-X841-1 & - Matrix 30 & \\
& $\rightarrow$ X41-5 & & \\
\hline Branch \& & C-X831-2 & - Coupling & Norm \\
Breaker Failure & $\rightarrow$ X41-40 & module F97 & al \\
Protection & & - CH2 & \\
& C-X831-1 & - Matrix 30 & \\
Sf6 Protection & $\rightarrow$ X41-6 & &
\end{tabular}

2.) Impedance Resistance Test (Megger) In table 7, following the Megger F97 input cable from channel 1 and channel 2 the GITET direction to the PLGTU.

Table 7 megger input cable to F97 results

\begin{tabular}{ccc} 
Cable Tagging & $\begin{array}{c}\text { Resistance } \\
\text { Value }\end{array}$ & Conclusion \\
\hline $\begin{array}{c}\text { C-X841-2 } \longrightarrow \text { X41 } \\
39 \text { (to Ground) }\end{array}$ & 1498 Mohm & 1500 Mohm \\
\hline $\begin{array}{c}\text { C-X841-1 } \rightarrow \text { X41-5 } \\
\text { (to Ground) }\end{array}$ & 1500 Mohm & 1500 Mohm
\end{tabular}


$\mathrm{C}-\mathrm{X} 841-2 \rightarrow \mathrm{X} 41$

39 to $\mathrm{C}-\mathrm{X} 841-1$

1498 Mohm $1500 \mathrm{Mohm}$

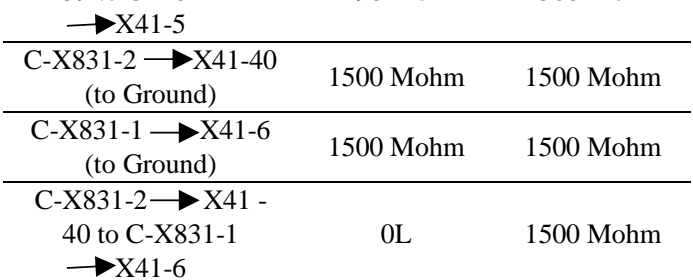

3.) Measurement of the resistance contact value on Branch Breaker Failure relay

In table 8 , following is a measurement of contact resistance for Branch Breaker Failure.

Table 8 measurement of contact resistance value

$$
\text { of BBF }
$$

\begin{tabular}{cccc}
$\begin{array}{c}\text { Name } \\
\text { Contact }\end{array}$ & $\begin{array}{c}\text { Resistance } \\
\text { (Before) } \\
\text { Score }\end{array}$ & $\begin{array}{c}\text { Resistance } \\
\text { (After) } \\
\text { Score }\end{array}$ & Conclusion \\
\hline $\begin{array}{c}\text { F513 } \\
\text { Relay }\end{array}$ & OL & OL & Normal \\
Contact & & &
\end{tabular}

In table 9, following is a test for Contact Branch Breaker Failure F513 and F97.

\begin{tabular}{lccc}
$\begin{array}{l}\text { Table } \\
\text { Interference } \\
\text { Type }\end{array}$ & $\begin{array}{c}\text { BBF testing F513 and F97 } \\
\text { Clarm }\end{array}$ & Trip Unit & Damage \\
\hline $\begin{array}{l}\text { Actual HV } \\
\text { Line }\end{array}$ & Yes & Yes & - \\
$\begin{array}{l}\text { Interference } \\
\text { Protection }\end{array}$ & & & \\
\hline $\begin{array}{l}\text { Input HV } \\
\text { Line }\end{array}$ & & Yes & $\begin{array}{c}\text { Cable / 513 } \\
\text { Relay }\end{array}$ \\
$\begin{array}{l}\text { Protection } \\
\text { with normal } \\
\text { conditions }\end{array}$ & Yes & & \\
\hline $\begin{array}{l}\text { Malfunctions } \\
\text { of trip relay } \\
\text { equipment in } \\
\text { generating } \\
\text { units }\end{array}$ & Yes & No & F97 Relay \\
& & &
\end{tabular}

In table 10 , following is the maintenance schedule for the GITET area.

Table 10 GITET maintenance schedule

\begin{tabular}{|c|c|c|c|c|}
\hline $\begin{array}{l}\text { Procedures } \\
\text { Profession }\end{array}$ & $\begin{array}{l}\text { Time } \\
\text { interv } \\
\text { al } \\
\end{array}$ & $\begin{array}{l}\text { Counter } \\
\text { Work } \\
\text { Equipment } \\
\end{array}$ & $\begin{array}{l}\text { Part } \\
\text { Mainte } \\
\text { nance }\end{array}$ & $\begin{array}{l}\text { Informat } \\
\text { ion }\end{array}$ \\
\hline $\begin{array}{l}\text { Visual } \\
\text { Check }\end{array}$ & $\begin{array}{c}5 \\
\text { Years }\end{array}$ & - & $\begin{array}{l}- \\
\text { Device } \\
\text {-PMT } \\
\text {-PMS }\end{array}$ & $\begin{array}{c}\text { Limited } \\
\text { outages } \\
\text { well- } \\
\text { maintaine } \\
\quad d \\
\text { equipmen } \\
t \text {, no need }\end{array}$ \\
\hline
\end{tabular}

evacuate

SF6 gas

\begin{tabular}{|c|c|c|c|c|}
\hline \multirow[t]{3}{*}{$\begin{array}{l}\text { Routine } \\
\text { Inspection }\end{array}$} & $\begin{array}{c}10 \\
\text { Years }\end{array}$ & $\begin{array}{c}1500 \\
\text { (normal) or } \\
3000 \text { (high) } \\
\text { x Drive } \\
\text { Mechanical } \\
\text { Work for } \\
\text { PMS and } \\
\text { soil PMS } \\
\end{array}$ & Device & $\begin{array}{c}\text { Limited } \\
\text { outages } \\
\text { well- } \\
\text { maintaine } \\
\mathrm{d} \\
\text { equipmen } \\
\mathrm{t} \text {, no need } \\
\text { to }\end{array}$ \\
\hline & & $\begin{array}{c}1500 \\
\text { (normal) or } \\
3000 \text { (high) } \\
\text { x Drive } \\
\text { Mechanical } \\
\text { Work }\end{array}$ & PMT & $\begin{array}{l}\text { evacuate } \\
\text { SF6 gas }\end{array}$ \\
\hline & & $\begin{array}{c}1500 \mathrm{x} \\
\text { Drive } \\
\text { Mechanical } \\
\text { Work } \\
\end{array}$ & PMS & \\
\hline $\begin{array}{l}\text { Visual } \\
\text { Check }\end{array}$ & $\begin{array}{c}15 \\
\text { Years }\end{array}$ & - & $\begin{array}{l}- \\
\text { Device } \\
\text {-PMT } \\
\text {-PMS }\end{array}$ & $\begin{array}{c}\text { Limited } \\
\text { outages } \\
\text { well- } \\
\text { maintaine } \\
d \\
\text { equipmen } \\
\text { t, no need } \\
\text { to } \\
\text { evacuate } \\
\text { SF6 gas }\end{array}$ \\
\hline
\end{tabular}

Continue of table 10 GITET maintenance schedule

\begin{tabular}{|c|c|c|c|c|}
\hline $\begin{array}{l}\text { Procedure } \\
\mathrm{s} \\
\text { Profession }\end{array}$ & $\begin{array}{l}\text { Time } \\
\text { interv } \\
\text { al }\end{array}$ & $\begin{array}{l}\text { Counter } \\
\text { Work } \\
\text { Equipment }\end{array}$ & $\begin{array}{l}\text { Part } \\
\text { Mainte } \\
\text { nance }\end{array}$ & $\begin{array}{l}\text { Informati } \\
\text { on }\end{array}$ \\
\hline \multirow[t]{3}{*}{$\begin{array}{c}\text { Major } \\
\text { Inspection }\end{array}$} & $\begin{array}{c}15 \\
\text { Years }\end{array}$ & $\begin{array}{c}3000 \\
\text { (normal) or } \\
6000 \text { (high) } \\
\text { x Drive } \\
\text { Mechanical } \\
\text { Work for } \\
\text { PMS and } \\
\text { soil PMS }\end{array}$ & Device & \multirow[t]{3}{*}{$\begin{array}{c}\text { Limited } \\
\text { outages } \\
\text { well- } \\
\text { maintaine } \\
\mathrm{d} \\
\text { equipmen } \\
\text { t, no need } \\
\text { to } \\
\text { evacuate } \\
\text { SF6 gas }\end{array}$} \\
\hline & & $\begin{array}{c}3000 \\
\text { (normal) or } \\
6000 \text { (high) } \\
\text { x Drive } \\
\text { Mechanical } \\
\text { Work } \\
\end{array}$ & PMT & \\
\hline & & $\begin{array}{c}300 \text { x Drive } \\
\text { Mechanical } \\
\text { Work }\end{array}$ & PMS & \\
\hline $\begin{array}{l}\text { Checking } \\
\text { the main } \\
\text { contact } \\
\text { area }\end{array}$ & - & $\begin{array}{l}\text { Based on } \\
\text { fault } \\
\text { Current } \\
\text { Calculation }\end{array}$ & PMT & $\begin{array}{c}\text { Limited } \\
\text { outages } \\
\text { well- } \\
\text { maintaine } \\
d \\
\text { equipmen }\end{array}$ \\
\hline
\end{tabular}




\begin{tabular}{|c|c|c|c|c|}
\hline & & & & $\begin{array}{c}\text { t, no need } \\
\text { to } \\
\text { evacuate } \\
\text { SF6 gas }\end{array}$ \\
\hline $\begin{array}{l}\text { Checking } \\
\text { the main } \\
\text { contact } \\
\text { area }\end{array}$ & - & $\begin{array}{l}\text { Based on } \\
\text { fault } \\
\text { Current } \\
\text { Calculation }\end{array}$ & PMS & $\begin{array}{c}\text { Limited } \\
\text { outages } \\
\text { well- } \\
\text { maintaine } \\
\text { d } \\
\text { equipmen } \\
\text { t, no need } \\
\text { to } \\
\text { evacuate } \\
\text { SF6 gas }\end{array}$ \\
\hline $\begin{array}{l}\text { Visual } \\
\text { Check }\end{array}$ & $\begin{array}{c}20 \\
\text { Years }\end{array}$ & - & & \\
\hline
\end{tabular}

- $\quad$ Failure Defense Task (FDT)

1. Short-term Failure Defense Task In table 11 , following is a short term failure defense task.

Table 11 short-term FDT

FDT 1 - Input cable looping test to F97

- Magger input cable to F97 channel 1 and channel 2 (label from GITET direction to PJB UP Gresik)

\begin{tabular}{|c|c|}
\hline Target & Normal measurement results \\
\hline FDT 2 & $\begin{array}{l}\text { - } \text { BBF protection F513 contact check } \\
\text { - Measurement of the contact resistance } \\
\text { value on the BBF protection F513 } \\
\text { relay }\end{array}$ \\
\hline
\end{tabular}

Target Normal measurement results

\begin{tabular}{ll}
\hline FDT 3 & Routine preventive maintenance \\
\hline Target & This maintenance is carried out to prevent
\end{tabular} recurring incidents and to find out the causes of disturbances and to increase the reliability of the electric power system at intervals of 1 year or 1 semester.

2. Long-term Failure Defense Task

In table 12, following is a long term failure defense task.

Table 12 long-term FDT

FDT 1 Proposed modification of the wiring system for the HV Line Protection side of the power unit

\begin{tabular}{ll}
\hline Target & $\begin{array}{l}\text { Added protection monitoring for the HV } \\
\text { Line system in order to determine } \\
\text { interference from internal and external }\end{array}$ \\
\hline FDT 2 & $\begin{array}{l}\text { Proposed modification of wiring on the } \\
\text { density side of high voltage (transmission } \\
\text { network) }\end{array}$ \\
\hline Target & $\begin{array}{l}\text { Added protection monitoring for the HV } \\
\text { Line system in order to determine } \\
\text { interference from internal and external }\end{array}$ \\
\hline FDT 3 & Routine corrective maintenance
\end{tabular}

Target This maintenance is carried out to prevent recurring incidents and to find out the causes of disturbances and to increase the reliability of the electric power system at intervals of 1 year or 1 semester

In this incident, several possible factors influence failure occurrence, namely from the internal side of the generator and the external side of the transmission network. This is very disturbing because it can cause the generating unit to trip and disconnect the network, even though the Gresik generation unit is very much needed by the Java Bali Network System, especially East Java Province and in particular to supply the Metropolitan city of Surabaya.

It can be seen from the measurement data that the failure that occurs in the protection HV Line is due to a false signal from the transmission which results in a Unit Trip. The false signal works even though there is no trip command from the transmission or generator, but the generator receives a trip command, causing the generator unit to trip. After further identification using the RCFA method in which there is a fishbone diagram, it is known that the failure occurred due to damage to the Branch breaker failure.

An alternative to recording event recorders, recording HV line events can use the Trap installation, with the following specifications:

Merk : Alshtom

Type : MiCOM P40 Agile

Statement of Conformity : The equipment has been supplied in accordance with a quality system certified to : ISO 9001:2008

Design

Techical Data $\quad: 1 \& 3$ pole tripping/reclosing

Additional event recorder equipment for recording $\mathrm{HV}$ Line events (special) for spurious signals picked up by the circuit. The delay time on the Trap HV line protection uses 1 second. If the captured signal is less than 1 second, the signal is declared a false signal and will not order the unit to trip, but if the captured signal is more than 1 second it can be stated that the signal is genuine and will perform a trip command on the generator unit.

\section{CONCLUSION}

Based on the identification results of the disturbances that occur in the HV Line Protection at the Gresik Generation Unit PLTGU Using the RCFA and FDT Methods, it can conclusion: 1. A trip of the unit due to HV Line Protection was caused by a false alarm that occurred from the Branch Breaker Failure Protection.

2. To prevent recurring events, several agreed FDTs (Failure Defense Tasks). 
3. This system can implement in other Generating Units that have the same problems as PLTGU Gresik so no failure causes the unit to trip due to false signals in protection.

\section{REFERENCES}

[1] Komari. (2003). Proteksi Sistem Tenaga Listrik Filosofi, Strategi dan Analisa Untuk Peningkatan Keandalan. Jakarta : PT PLN (Persero) Jasa Pendidikan dan Pelatihan.

[2] Marsudi, D. (2005). Pembangkitan Energi Listrik. Jakarta: Erlangga.

[3] Sutrisno. (2000). Sistem Proteksi Tenaga Listrik. Bandung: Institut Teknologi Bandung.

[4] Samaulah, Hazairin. 2000. Dasar-Dasar Sistem Proteksi Tenaga Listrik. Palembang: Unsri.

[5] Mobley, R. Keith, 1999. Root Cause Failure Analysis, USA: Butterworth Heinemann.

[6] Grover, V., Bussiness Process Change ; re-engineering concepts, method, and technologies, Idea Group Publishing, Harrisburg, P.A., 1995 , p.208-40. 